\title{
Visual assessment of San Antonio Franciscan Mission churches in San Antonio for sustainable cultural heritage tourism
}

\author{
S. T. Beeson \& S. Doganer \\ The University of Texas at San Antonio, College of Architecture, USA
}

\begin{abstract}
In San Antonio of Texas the Catholic Church and the Spanish government established mission compounds and a small military base in the $18^{\text {th }}$ century. These were part of Spain's territorial expansion northward from Mexico. At the missions, native people were introduced to Catholicism, Spain's national religion, and in order to learn trade, the Spanish-language, and citizenship skills they would need to join Spanish society. On each mission's extensive farm fields and grazing lands, residents grew their own food. With more than 80 structures surviving, the mission compounds are a tangible and well-preserved representation of the influence of Spain in the New World.

The missions were all located close to the San Antonio River. All missions are protected historic sites, hosting millions of local and out-of-town visitors each year. To promote their historical significance officially, the missions were nominated as a World Heritage Site. The nomination will be reviewed in 2015. If the decision about including the missions on the list of the best of the world's natural and cultural heritage is accepted, the economy of the region will be catalyzed and the tourism value will exponentially increase.

One of the initial steps of this attempt is the conservation of the structures that comprise the San Antonio Missions. The structural condition of the monuments has to be assessed to start up the conservation process regarding the whole area. There are various ways to assess the condition and safety of historic monuments. In this study, the churches, as the dominating pieces of the San Antonio Missions, are visually assessed. The assessment results will form the basis for further detailed structural analyses for a more reliable assessment of the monuments. The findings will be discussed with regard to any further
\end{abstract}


conservation attempts that will involve the monuments with their surrounding landscape.

Keywords: cultural heritage tourism, San Antonio Franciscan Missions, Visual assessment, Mission Concepcion, Mission San Jose, Mission San Juan, Mission Espada.

\section{Introduction}

Tourism is one of the world's fastest-growing industry and business. International tourist arrivals grew by over 4\% in 2011 to 980 million, according to the latest UNWTO World Tourism Barometer. The Americas (+4\%) saw an increase of 6 million arrivals, reaching 156 million in total. North America, with a 3\% increase, hit the 100 million tourists mark in 2011 [1]. According to the Economic Impact of San Antonio's Hospitality Industry report, from 1998 to 2008, the economic impact of the hospitality industry increased by more than 70\%. In San Antonio alone, hospitality industry employs more than 113,000 workers who annually generate $\$ 12.2$ billion dollars back into the local economy; making tourism one of San Antonio’s largest industries [2].

San Antonio is one of the State's top tourist cities. The city has a rich and unique historic urban landscape characterized by its river with its famous 'Riverwalk', historic neighborhoods and major landmarks such as San Antonio Franciscan Missions, which are on the U.S. "tentative list” as possible UNESCO World Heritage Sites. The missions are $18^{\text {th }}$ century works of the Catholic Church and Spanish government. They were part of Spain's territorial expansion northward from Mexico. At the missions, native people were introduced to Catholicism, Spain's national religion, and learned trade, Spanish-language, and citizenship skills they would need to join Spanish society. With more than 80 structures surviving, the mission compounds are a tangible and well-preserved representation of the influence of Spain in the New World.

Regarding the importance of the Franciscan missions on the tourism potential and, consequently, economy of San Antonio, it is crucial to develop a well thought out plan for conservation of these sites. Conservation of historical buildings starts with a detailed observation and analysis of the structures. This study aims to evaluate the physical conditions of the mission churches, which are the dominating pieces of the missions. The features of mission churches are explained in detail regarding all the conservation history that might explain their current situation. After a careful visual inspection, outstanding issues such as cracks, deteriorations, settlements, and peelings were specified. The findings are compared to the reports of San Antonio Missions National Historical Park to understand the progress of the cracks and deteriorations as well as the effects of the conservation procedures conducted on the buildings.

\section{San Antonio Franciscan missions}

The four colonial Spanish missions are sited along the San Antonio River for a nearly thirteen-kilometer (eight-mile) span [3]. These eighteenth century 
complexes are built in the Spanish vernacular tradition with monumental stone masonry buildings.

The dominating piece at each mission complex was the church. Though varied in design, most were cruciform and all were constructed of limestone, mined from nearby quarries. All the churches were decorated and painted. Normally attached at one wall of each church was a convento, which provided living accommodations and offices to the mission priest(s) and assigned staff. The conventos were also constructed of stone and were decorated.

Table 1 shows the formal and the popular names of the missions along with the dates of establishment. For the rest of the study, the popular names are used to address the missions.

Table 1: $\quad$ San Antonio Franciscan missions [4].

\begin{tabular}{|l|c|c|}
\hline Formal Name & Popular Name & Date of Establishment \\
\hline $\begin{array}{l}\text { Mission Nuestra Senora } \\
\text { de la Purisima } \\
\text { Concepcion de Acuna }\end{array}$ & Mission Concepcion & 1716 \\
\hline $\begin{array}{l}\text { Mission San Jose y San } \\
\text { Miguel de Aguayo }\end{array}$ & Mission San Jose & 1720 \\
\hline $\begin{array}{l}\text { Mission San Juan } \\
\text { Capistrano }\end{array}$ & Mission San Juan & 1716 \\
\hline $\begin{array}{l}\text { Mission San Francisco } \\
\text { de la Espada }\end{array}$ & Mission Espada & 1716 \\
\hline
\end{tabular}

\subsection{Mission Concepcion}

Mission Concepcion was moved to San Antonio around 1731. It is located south of San Antonio's city center. The construction was completed around 1755. The church, convento, and various workshops and support buildings formed the southeast corner of the mission complex, with the open plaza of the complex to the west and the north of the church. The mission was secularized in 1824 and was used as a supply depot until its reuse as a religious facility [5].

Dominated by twin bell towers, the church of Mission Concepcion is cruciform in plan with a barrel-vaulted masonry roof and prominent dome and lantern at the transept crossing. Measuring 28.3 meters (93 feet) long and 16.2 meters (53 feet) wide at the transepts, the church reaches an interior height of 13.4 meters (44 feet) at the apex of the dome. The 1.2 meter (4 feet) thick walls are constructed of load-bearing, rubble-faced tufa limestone blocks quarried on site and feature buttresses along the north and south walls of the nave. The façade is characterized by symmetrical towers at the north and south, which rise some 15.8 meters (52 feet) above roof level, and a carved limestone portal at the center, forming a striking composition that is a fine example of the more austere late Baroque of New Spain. The carved stone portal is characterized by a large pediment resting on an entablature supported by engaged columns flanking a polygonal arch doorway. Within the portal is a carved crucifix above a shellform carved niche with engaged columns. The stonework displays various 
carved geometric patterns and stylized floral motifs. Several Franciscan emblems, including the cord with four knots, the stigmata of St. Francis, and the monstrance in the keystone medallion, indicate the foundation of this mission church. The west façade and bell towers were originally coated with stucco and decorated with sumptuous painted polychrome geometric patterns and motifs. Fortunately, almost $65 \%$ of the total surface area of the west elevation is still covered with stucco and remnants of the incising and painted decoration $[6,7]$.

Mission Concepcion's church and its adjoining former convento retain the highest level of existing historical fabric of any of the San Antonio missions. The church is the only $18^{\text {th }}$ century mission church in the western Hemisphere that has not required major repairs since its construction as the roof, dome and walls are still original [7].

\subsection{Mission San Jose}

Mission San Jose is the largest of the mission complexes in San Antonio. It comprises many features including the church and convento, granary, indigenous living quarters along the perimeter walls, a gristmill, portions of the acequia, and remnants of lime kilns. The construction took more than 30 years, between 1749 and 1782 [8].

Known as the "Queen of the Missions," this imposing complex is defined by a substantial open square, which is enclosed on all four sides by high stone walls and various structures built to support the mission's objectives. The impressive church and extensive ruins of its convento are positioned at the north end of the complex.

The large, single-aisled church dominates the mission compound. Standing 33.5 meters (110 feet) long and 10.1 meters (33 feet) wide, the church is built primarily of local dressed tuffa limestone with some sandstone laid up in lime mortar, and is reinforced with buttresses [7]. The entrance is distinguished by a single bell tower at the southwest corner and an elaborate double-height entrance portal of carved local limestone. Characterized by a profusion of intertwining floral elements and large three-dimensional sculptures of various saints, the carved stonework retains a remarkably high degree (approximately 70\%) of original fabric.

On the church interior, the nave is divided into five bays with a groin vaulted ceiling with transverse arches and a dome on pendentives that is 18.3 meters (60 feet) high at the interior apex. Walls are finished with painted plaster and decorative banding that date to a 2011 restoration based on investigation and analysis of original colonial plaster remnants. A choir loft sits above the west entrance, accessed by a spiral wooden staircase inside a smaller round tower, built against the east side of the bell tower. Connected to the nave along the south wall is a single-storied sacristy with three low domes. On the exterior of the sacristy is a carved limestone window, popularly known as the "Rose Window.” Displaying a similar use of floral motifs and shell forms as the façade, this window also exhibits the remarkable skill of the Colonial craftsmen. 


\subsection{Mission San Juan}

Mission San Juan was also moved to San Antonio in 1731. Construction lasted from 1756 to 1790 . As the construction of the church building, which started in the 1770s, could not be completed for a long time, the granary was modified and served as the church building between 1786 and 1790 [9].

Mission San Juan is located in a mostly rural section of San Antonio and retains much of its surrounding open land including labores, or the farm fields, as well as the original dam and acequia. These elements, together with the mission complex - the church, convento, remnants of native quarters, support structures and perimeter walls - provide an exceptional insight into the original appearance of the San Antonio Missions during the colonial era. Stabilized foundations of various support structures and the original perimeter walls form the remainder of the enclosed rectangular complex. The acequia, located to the southeast of the complex, runs towards the adjacent labores, and is fed by water traveling from several kilometers to the north. A nature trail runs along the south side of the complex.

The long, rectangular church of Mission San Juan stands 30.8 meters (101 feet) long by 6.1 meters (20 feet) wide and 5.6 meters (18.5 feet) high. A bell gable with three arched openings rises about 12.6 meters (41.5 feet) above the main entrance to the church at the north end of the main (east) façade [7]. Construction is of rubble sandstone and limestone masonry set in lime mortar, with plastered north, east, and south exterior walls and a flat roof. The church does not follow the conventional east-west orientation; instead the altar is located at the south end because the structure originally served as a granary, before its conversion to a church. The main (east) façade has three entrance doors and a series of six engaged piers with blind segmental arches that correspond to the engaged pilasters on the interior walls. The sacristy is located on the south end behind the altar. Interior walls are decorated with painted lime plaster and the clay tile roof is supported by large wooden purlins.

\subsection{Mission Espada}

Mission Espada was moved from East Texas to its outlying position in 1731. Construction of a friary was completed in 1745 followed by completion of the church building around 1756. Located at the very southern end of the district, Mission Espada is the most rural mission of San Antonio. The Espada acequia system, dam, and aqueduct have functioned continuously for more than 265 years, making it the oldest continuously operating irrigation system in North America. The Espada acequia system continues to define farm field boundaries in the area [7].

Located approximately 170 meters (558 feet) from the west bank of the San Antonio River, the layout of Mission Espada reflects several phases of building during the colonial and post-colonial periods. The modest church and adjacent convento and garden stand along the west wall of the complex. To the southwest of the church are ruins of a granary and late colonial- church. The south wall contains ruins of a late-colonial granary and several indigenous living quarters. 
Various indigenous living quarter ruins and remnants of perimeter walls form the north, northwest and east portions of the complex. A rounded bastion tower stands at the southeast corner of the complex near the mission's visitor center and museum.

Constructed of coursed rubble sandstone and limestone masonry set in lime mortar, the one-story church is cruciform in plan with shallow transepts and measures 19.8 meters (65 feet) long by 7.6 meters (25 feet) wide. The main façade (west elevation) is original to the colonial era and is distinguished by a large espadana containing three bells and a Moorish-style, mixtilinear arched doorway built of dressed limestone. The interior is a single large room; with a raised sanctuary space at the west end, decorated with painted plaster walls; the ceiling has exposed wooden beams. The sacristy, approximately 3.7 meters (12 feet) long by 4.3 meters (14 feet) wide, adjoins the church at the south end of the sanctuary and links the church to the modern convento to the south [7].

\section{The impact of San Antonio Missions on sustainable cultural heritage tourism}

San Antonio Franciscan Missions play an important role in defining the city's culture. They are on the U.S. "tentative list" to be advanced as possible UNESCO World Heritage Sites. Collectively, Missions Concepcion, San Jose, San Juan, and Espada missions and associated features - including acequias (irrigation canals), labores (farm lands), dam and aqueduct, and the single remaining rancho (mission ranch) - comprise the San Antonio Missions National Historical Park [2]. The area also designated as the Mission Historic District, located along the San Antonio River in the south section of the city, originally attracted both prehistoric Indian and historic Spanish and Anglo populations because of the prevalence of unique natural resources. The historic San Antonio River has long served as the heart of the city. Each year the worldrenowned River Walk draws millions of visitors, yet miles of urban river with untapped potential lie beyond downtown and the famed Paseo del Rio. A comprehensive, multi-year project is underway to restore and enhance 13 miles of the San Antonio River both north and south of downtown. A multi-phase project to develop the full potential of the San Antonio River is focusing on improving two sections of the river-Museum and Mission Reaches - that pose different challenges. The Mission Reach segment overlays with the research area of this paper, and provides a strong connection between the area and downtown. It is expected that the river improvement project will also reinforce the connection to the San Antonio Missions, and encourage visitors to circulate along the river beyond the downtown area.

In 2009, over 1.7 million people visited Missions Concepcion, San Jose, San Juan, and Espada while 26 million people visiting the city San Antonio in total.

San Antonio River Improvement Project and current consideration for World Heritage designation of the San Antonio Missions will also bring international attention to the district, accelerate cultural heritage tourism, and provide "high profile cataylist" for even more cultural visitations. The Harbinger Consulting 
Group states, "Cultural travelers, whether domestic or international, look for experiences that are unique to a place. The World Heritage Site (WHS) can be used to capture the attention of these potential visitors, but they will be looking for other high quality, engaging, authentic cultural experiences to augment their WHS visit. Use WHS designation as a catalyst for developing and connecting other heritage tourism opportunities and local businesses” [10].

Tourism can be a positive force for the preservation of World Heritage as it draws world attention to their importance. However, the unprecedented growth of tourism raises a number of concerns over the environmental and cultural integrity of these destination areas within the concept of sustainable development, which is defined as preserving the environment while allowing for cultural, economic, social, and political development. In other words, sustainable development ensures accommodation of the needs of the visitor while managing the site in a way to preserve its prosperity $[11,12]$.

\section{Developing method and criteria for the assessment of the mission churches of San Antonio}

The mission churches, which represent the largest concentration of cultural resources from the Spanish colonial period in the United States, are among the most valuable cultural assets of San Antonio. Unfortunately, there have been times of negligence after the secularization in 1824. Even though all four of the mission churches serve as churches today, there were times that the buildings were abandoned or used for different purposes. In 1978, San Antonio Missions National Historical Park was founded; and today it is in charge of preserving the missions.

The aim of the assessment conducted for the four Francescan Mission Churches in San Antonio is to generate information about the condition of the monuments and, if any, determine the specific need for preservation or rehabilitation.

The selection of the parameters that would be used in the assessment is, though obvious, critical. Particularly the structural members, which, in this case are the walls, roofs and the domes (if applicable), are carefully addressed as they are the parts that hold the whole building intact. The structures are checked visually for any partial collapses, cracks, visible deformations, and material deteriorations to determine their physical conditions. Depending on the complexity of the building's geometry and layout, the load bearing schemes are considered to simplify the assessment of the risk level of the structural members.

The church buildings that are observed for this study are similar in many ways. They belong to the same age; they are constructed with local materials; they are rectangular in plan; and they have similar topographic conditions. Regarding the hot and humid weather conditions of San Antonio, one of the basic concerns is material deterioration due to humidity. Also, cracks are observed carefully to understand any possible threat to the overall stability of the structures. The findings are compared to the data obtained from the reports of 
the San Antonio Missions National Historical Park to understand the progress of the damages listed before.

\section{Previous conservations on San Antonio Mission Churches and present condition assessment}

The churches of San Antonio missions have experienced change of function, repairs, modifications and/or restorations throughout their lifetimes. Among them all, the church of Mission Concepcion is the only one of the San Antonio mission churches that has retained its original dome and roof throughout its history [5]. It retains a high level of historic fabric, including its original dome and portions of its interior frescos.

The Concepcion Church is known to have been used as a cattle pen and have been desecrated with animal filth in the $19^{\text {th }}$ century. The church was repaired in late $19^{\text {th }}$ century. In the 1930 s, repairs were made to the roof and parapets. The restoration project carried out in 2010 uncovered the multicolor banding on the remaining colonial-era plaster beneath later $19^{\text {th }}$ century plaster. The interior of the church was repainted in this process. Through the use of modern computer technology, the paint used perfectly matches the colors found on the fragments of Spanish Colonial paint that still existed in the church [7].

In the visual assessments conducted in the church of the Mission Concepcion, deterioration is the main concern at the outer façade (Figure 1). Deteriorated mortar and honeycombed stones are detected at the bottom parts of the western wall. The stones are deteriorated through the entire length of the northern wall and on the stones surrounding the tower openings.

The interior walls of the church show indications of moisture as well. There is rising damp on the southern wall, and peelings on the paints on transept walls (Figure 2). The other parts of the church that were specified as problematic due to moisture were fixed in the last restoration process conducted in 2010. Most of the cracks were also fixed with an exception of those on the ceiling of the transept.

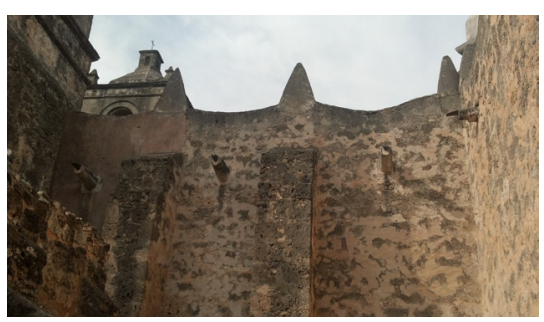

Figure 1: $\quad$ West façade around the Figure 2: courtyard.

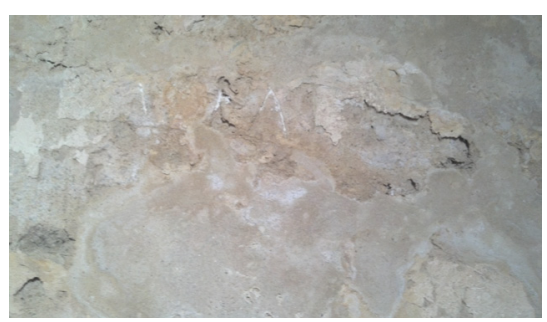

Peelings on the transept walls.

The church of Mission San Jose has undergone several restorations after the secularization in 1824. It continued to serve as a church into the mid 1800s; 
however, it was damaged by the soldiers between 1841 and 1850. In 1868, part of the north wall of the church and a part of the original dome collapsed. On December 25, 1874, the remaining parts of the dome fell in during services. The main doors of the church were stolen sometime between 1880 and 1890. In 1937, the church was rededicated and restoration work was undertaken on the church, especially on the rear wall. In 2006-07 the foundations of the south side of the sacristy and church were also cleaned, repointed, and poulticed to remove salts. A new drainage system was installed to pull water away from that side of the building and it was linked to a new drainage box that was installed in 2000 to pull water away from the front of the church.

After this process, the church underwent a multi-phase, three year long stabilization and conservation program, which is completed in 2012. The carved stone façade, which is a masterpiece of Spanish Baroque ornament, was repaired and the interior was repainted with matching colors of the $18^{\text {th }}$ century. Walls are finished with painted plaster and decorative banding that date to a 2011 restoration based on investigation and analysis of original colonial plaster remnants [7].

Until the recent restorations, the most serious problems threatening the integrity of the church structure were related to the drainage problem in the mission site. Rising damp around the entire building, honeycombing and deterioration on the stones, deterioration on mortar, and plants growing on the walls were among the problems encountered in and around the building. Today, there are no plants or missing stones on the walls; however, it is possible to see deteriorations on the western and northern façade, which also has a few bad stones (Figure 3).

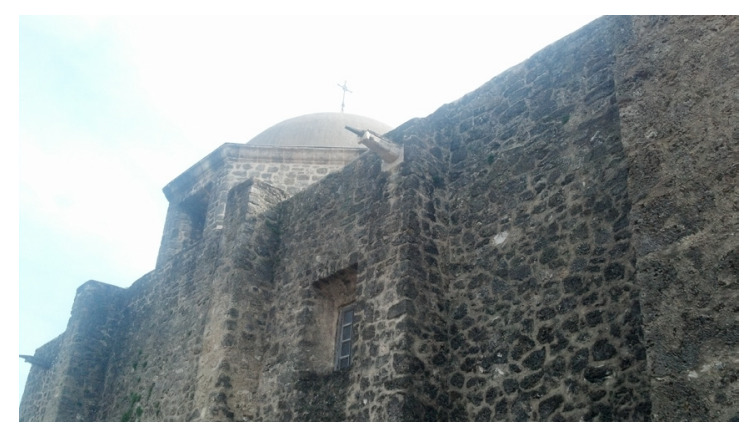

Figure 3: Deteriorations on the north façade.

Despite the negligence that Mission San Juan endured following the secularization in 1824, most of the quarters remained intact and were occupied until at least 1850. The mission church was saved from complete ruin in 18581886. The roof totally collapsed in 1865 . Local residents rehabilitated the church by rebuilding the roof in 1877 for continued use, which lasted until the storm in 1886 [5]. The church fell into significant despair until the installation of a new roof and beaded ceiling in 1910. The floor and the altar were replaced and two 
skylights were added. In 1934 the walls were partially rebuilt and the roof was replaced. The restoration conducted in 1960s focused mainly on the church building. In 1968 buttresses were added to the outer wall; and in 1969-1970 the floor was lowered to its original level; layers of nonoriginal plaster were removed and replaced from the interior walls; the choir loft was removed; and new altars were installed. A modern flat roof completed the work. The roof was replaced again in 1998. The church foundations were stabilized in 2012 [7].

The survey report from the San Antonio Missions National Historical Park shows significant cracks on the eastern and western outer walls of the church [9]. Today these cracks do not exist anymore. However, it is suggested to monitor the church for further cracks to rule out any possible issues due to foundation settlement after the last works carried out in 2012. The outer walls are completely plastered; hence it is not possible to observe any deterioration on the masonry units or mortar (Figure 4). There are thin cracks on the interior walls, which could be seen as plaster cracks regarding their width. The platform installed on the northern end of the church is not causing extra load on the church walls, as it is not supported by them; however, it is fixed on the tiles of the church.

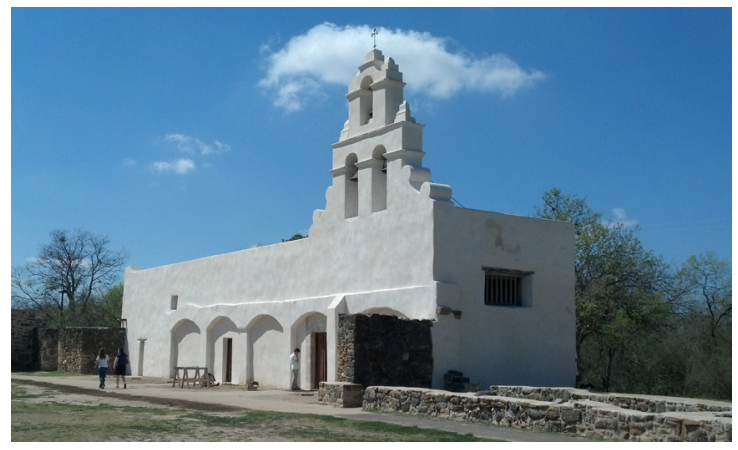

Figure 4: $\quad$ San Juan Mission Church.

Mission Espada is another complex that is greatly neglected after the secularization. It sustained heavy damage that was not fully repaired until $20^{\text {th }}$ century.

As the construction of the church did not go further than the foundation level in this mission, the sacristy was used for religious purposes. In 1762, the construction of the new church began. However, it had to be dismantled in 1777 due to structural problems. The granary was remodeled to serve as the church. In 1777, the original church was repaired, enlarged and opened for service along with the additions of campanario and bell tower. The adjacent convento room was remodeled to become the sacristy [13].

The survey report from the San Antonio Missions National Historical Park states that only the front and back walls of the church were standing in 1880s. Over the next few years the church was restored. In 1911 most of the north transept and the choir loft were removed. Doors and windows were replaced. 
Wood ceiling and brick floor were added. The church underwent a major refurbish in 1955-1958. The interior was renovated including a new ceiling and floor. New roof was installed. Following the problem reports in 1960 the west wall of the church was totally rebuilt and the other walls were repaired and the sacristy was remodeled. In 1998, a fire due to an electrical short circuit damaged the ceiling and roof [13].

Today, the church building remains intact. Material loss, mortar in particular, is detected on the west outer façade (Figure 5). Cracks, though patched, are visible on the eastern and northern façade (Figure 6). Especially the cracks on the northern façade are critical and they threaten the structural integrity of the building. Though it is possible to spot them on the walls as well, they mostly originate at the top of the arched openings and proceed in both linear and angular directions.

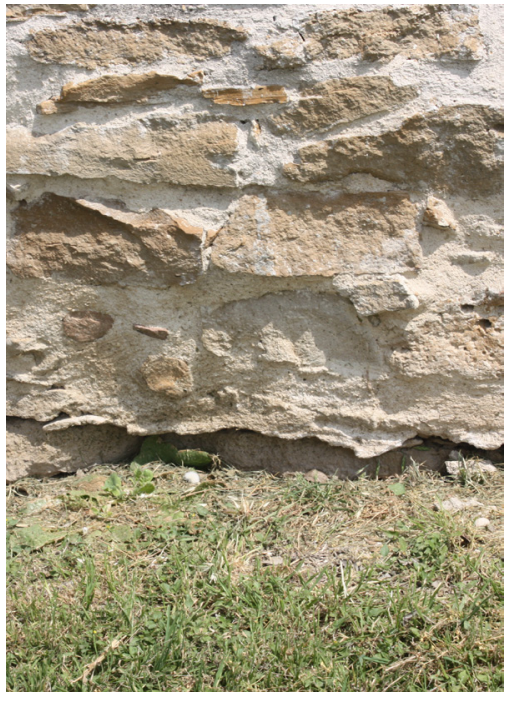

Figure 5: Material loss on the west façade.

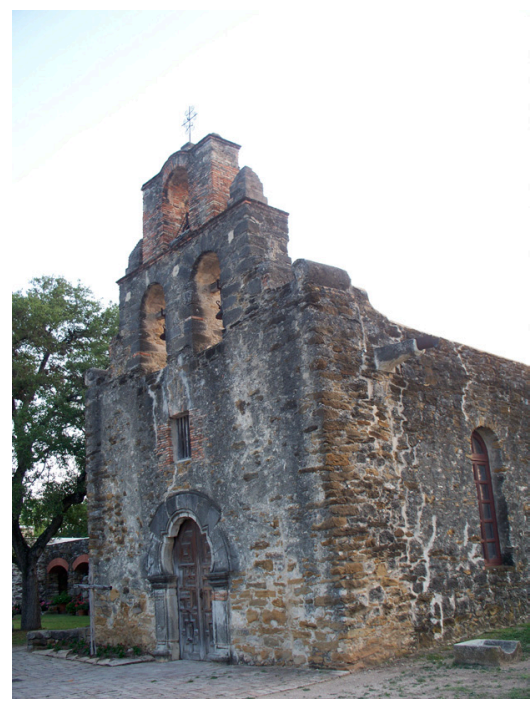

Figure 6: Cracks on the north and east façades.

\section{Conclusions}

In this study, the churches of the San Antonio Franciscan Missions are visually assessed to explore their current physical conditions as they are among the invaluable historical assets of San Antonio. The missions were greatly neglected after the secularization in 1824. They were abandoned, used for different purposes or severely damaged. They have experienced some conservation attempts throughout their lifetime; however, as quite a few of these attempts were not conducted by the professionals, some of the original qualities and 
features got lost and could not be sustained. It is recommended to continuously monitor the structures to prevent any serious damage.

Conservation of the missions and their environment is crucial to bring out the cultural significance of San Antonio for community. In addition, current consideration for World Heritage designation of the San Antonio Missions will also bring international attention to the district and stimulate cultural heritage tourism. However, a careful conservation management should be maintained to minimize the effects of heavy visitation that could cause physical damage $[14,15]$.

\section{References}

[1] Kester, J.G.C., 2012. 2011 International Tourism Results and Prospects for 2012, UNWTO News Conference, HQ, Madrid, Spain, 16 January 2012. http://dtxtq4w60xqpw.cloudfront.net/sites/all/files/pdf/unwto_hq_fitur12_j k_2pp_0.pdf

[2] UTSA Institute for Economic Development's Center for Community and Business Research in conjunction with The Harbinger Consulting Group, 2011. Economic Impact of the San Antonio Missions, National Historic Parks, http://ccs.utsa.edu/pdf/EconomicImpactMissions.pdf

[3] City of San Antonio, Office of Historic Preservation. A Guide to San Antonio's Historic Resources, http://www.sanantonio.gov/historic/Docs/ DesignGuidelines/7_GuidetoSanAntonio'sHistoricDistricts.pdf

[4] San Antonio Missions History, http://www.missionsofsanantonio.org/samission-history.html

[5] SAAN Historical Architect, 2003. San Antonio Missions: Condition Assessment and Preservation Analysis: Volume 1, San Antonio Missions National Historical Park Library, Unpublished library material, San Antonio, Texas

[6] Bass, A. and Porter, D., 2012. Mission Concepción Exterior Finishes Survey 2011, Sante Fe, New Mexico: Conservation Associates LLC.

[7] San Antonio Missions National Historic Park. San Antonio Franciscan Missions World Heritage Nomination Draft, Unpublished Report, San Antonio, Texas

[8] SAAN Historical Architect, 2003. San Antonio Missions: Condition Assessment and Preservation Analysis: Volume 2, San Antonio Missions National Historical Park Library, Unpublished library material, San Antonio, Texas

[9] SAAN Historical Architect, 2003. San Antonio Missions: Condition Assessment and Preservation Analysis: Volume 3, San Antonio Missions National Historical Park Library, Unpublished library material, San Antonio, Texas

[10] The Harbinger Consulting Group, 2013. Building on a Strong Foundation: Potential Economic Impact of World Heritage Site Designation for the San Antonio Missions, http://www.bexar.org/whs/Missions_WHS_Report.PDF 
[11] Drost, A., 1996. "Developing Sustainable Tourism For World Heritage Sites", Annals of Tourism Research, Volume 23, No. 2, pp. 479-492

[12] Millar, S., 1989. "Heritage Management For Heritage Tourism”, Tourism Management, Volume 10, Issue 1, March 1989, pp. 9-14

[13] SAAN Historical Architect, 2003. San Antonio Missions: Condition Assessment and Preservation Analysis: Volume 4, San Antonio Missions National Historical Park Library, Unpublished library material, San Antonio, Texas

[14] Cros, H., 2001. “A New Model to Assist in Planning for Sustainable Cultural Heritage Tourism”, International Journal of Tourism Research, Volume 3, Issue 2, March/April 2001, pp. 165-170

[15] Li, M., Wu, B., Cai, L., “Tourism Development of World Heritage Sites in China: A Geographic Perspective”, Tourism Management, Volume 29, Issue 2, April 2008, pp. 308-319 